\title{
The Role of the Underlying Real Asset Market in REIT IPOs
}

\author{
Jay C. Hartzell, The University of Texas at Austin \\ Jarl G. Kallberg, New York University \\ Crocker H. Liu, New York University
}

\begin{abstract}
A leading explanation for IPO cycles is time-varying supply and demand for the underlying assets of the firms that are considering going public. We test this hypothesis using REIT IPOs, taking advantage of the relative transparency of the underlying real asset markets. We document links between REIT IPO activity and both the conditions of the underlying real estate market and the price of REITs. We find no significant relation between the heat of the IPO market and post-IPO operating performance, implying homogeneous firm quality across IPO cycles. Finally, we show that lagged IPO proceeds are related to future increases in investment and in capacity utilization.
\end{abstract}

Initial public offerings have provided a rich arena for theoretical and empirical analysis. The theoretical approaches are diverse and often center on the asymmetric information characteristics of IPOs: Given that managers of the firm know more about the firm's prospects than potential equity investors, how should markets react to an IPO announcement? On the one hand, we might expect managers to exploit their informational advantage and issue equity only when markets overvalue their assets. This would imply relatively poor long-term performance of IPOs, via a lemons or adverseselection explanation. Conversely, high levels of IPO issuance might signal positive information about the industry's prospects or future investment opportunities. This demand for investment capital would lead firms to issue equity in order to undertake favorable projects. In addition, firms could also deliberately underprice in order to signal quality in anticipation of a subsequent seasoned equity offering, as in Welch (1989). These two possibilities would not predict poor future performance of IPO firms.

These conflicting theoretical predictions have spawned a very broad array of empirical research. Ibbotson and Ritter (1995) partition this literature into three parts: initial-day underpricing, long-term underperformance of IPOs and cycles of hot and cold IPO markets. While initial-day underpricing is almost universally found in the many domestic and international studies, the evidence on long-run 
behavior provides no clear consensus. Ritter (1991) computes an industry-adjusted, 3-year return of $15 \%$ and provides evidence that firms that issue in hot markets tend to be of poorer quality than their peers. In contrast, Helwege and Liang (2004) find little difference between firms that issue in a hot market and those that issue in a cold market.

Additional insight into these important questions can be obtained by focusing the analysis on a restricted class of equities, real estate investment trusts (REITs), rather than on all IPOs. This study empirically addresses these issues by examining the relation between IPO performance and the underlying real assets. We study 189 REIT IPOs completed between the beginning of 1980 and the end of 1998. ${ }^{1}$ We use REITs for this study for five major reasons: (i) to take advantage of the availability of detailed information on the underlying real asset markets; (ii) to focus on a single-industry sector (several theoretical papers on IPOs attribute the clustering of IPOs to positive shocks to an industry's prospects); (iii) to address further the conflicting literature on REIT IPOs; (iv) to analyze an industry where the problems of asymmetric information and managerial self-dealing may be mitigated due to transparency of the underlying real asset market and constraints on managerial discretion and (v) since REITs are a tax conduit, the decision to raise equity rather than debt is not influenced by tax effects.

Our study complements the earlier (sometimes conflicting) evidence on REIT IPOs. Wang, Chan and Gau (1992) document a period of REIT overpricing together with poor performance over the first 120 days of trading. Ling and Ryngaert (1997), using a later time frame, document underpricing for REIT IPOs and find positive abnormal performance up to 100 days after the offering. They attribute this change to increased information asymmetry in the market for REITs.

More recently, Buttimer, Hyland and Sanders (2005) analyze the long-term stock-market performance of REIT IPOs. In contrast to much of the literature on regular corporations, they find no evidence of abnormal post-IPO stock performance. Our study differs from these three in that our focus is on the degree to which the characteristics of the underlying "real" real estate markets (such as returns on unsecuritized commercial real estate, vacancy rates, the supply and demand for space and REIT dividend yields) can help explain REIT IPO volume, initial-day returns and long-term abnormal operating performance. Further, to the extent that we analyze post-IPO performance across cycles, we focus on operating performance rather than stock market performance. This has two advantages: It avoids the econometric difficulties in statistical tests of long-term, abnormal stock price performance, and it also evades the joint hypothesis problem inherent in attempting to disentangle abnormal stock market

\footnotetext{
${ }^{1}$ REITs are excluded from almost all empirical IPO studies, usually with very little explanation for this omission.
} 
performance and market efficiency. In addition, to our knowledge, this study is the first to supply direct tests of the hypothesis that IPO waves are driven by investment demand. ${ }^{2}$

We expect our results to differ from those found for the average industrial IPO. Indeed, the REIT IPO market is not closely related to the broader IPO market. For example, in our data set, the contemporaneous correlation between REIT initial-day returns and average industrial IPO initial-day returns is -0.062 . The correlation between the number of REIT IPOs and the number of industrial IPOs is 0.291 .

One reason for this separation noted in point iv above is that the institutional structure of a REIT is very different than that of the typical corporation. These factors limit the degree of discretion a manager has by mandating a high dividend payout ${ }^{3}$ and by restricting the types of activities in which a REIT may engage. These limitations reduce the manager's divertible free cash flow. An additional control on managerial discretion is the transparency of the underlying real asset market, which allows owners to more easily evaluate managers. Finally, as noted above, since REITs are a tax conduit, the tax shield from leverage is unavailable, taking away one of the most important benefits of debt versus equity issuance. This should decrease the cost of equity relative to debt, making equity issuance less of a negative signal of firm quality than it is for the typical corporation.

Collectively, these characteristics suggest that IPO models that are driven by informational asymmetries are less likely to be able to explain the behavior of REIT IPOs (compared to regular corporations). ${ }^{4}$ But, due to this reduced role of information asymmetry and the transparency of the asset market, REITs should provide an especially powerful test of the link between underlying asset markets and IPOs. When interpreting our results, though, there is an open question as to the ability of one to generalize to the broader corporate IPO setting, especially in industries where information asymmetry is important.

To briefly summarize our key results, we find that both IPO volume (our measure of "hot supply" for REIT IPOs) and initial-day returns (our measure of "hot demand") are related to the state of the underlying real markets. We provide evidence that is consistent with the "heat" of the REIT IPO market

\footnotetext{
${ }^{2}$ Our study thus contributes to an area of empirical research that has put relatively little emphasis on attempting to explain underpricing and post-IPO performance by ex ante observable data. The most closely related work in this area is by Bradley and Jordan (2002), who show that a significant amount of IPO underpricing can be explained by overhang (the ratio of pre-IPO shares to IPO shares sold), filing range amendments, the influence of venture capital backing and the trend in IPO returns.

${ }^{3} 3$ During the time period of our study, REITs were required to pay out at least $95 \%$ of taxable income as dividends. However, this constraint is seldom binding; see Kallberg, Liu and Srinivasan (2003).

${ }^{4}$ The recent research on REIT seasoned equity offerings (Ghosh, Nag and Sirmans 1998, Friday, Howton and Howton 2000) documents significant differences between the behavior of REITs and the typical industrial firm.
} 
being a function of both underlying markets and relative REIT prices. We also find that, while the performance of the real market is significant in explaining the supply-side definition of hot markets, dividend yield is both statistically and economically more significant and is the only variable significantly related to the demand-side definition of hot markets. Furthermore, future abnormal operating performance (as measured by return on assets and return on market equity relative to the median REIT) does not depend on whether the REIT IPO occurred in a hot or cold market. This conclusion is robust to our characterizations of hot or cold markets, implying homogeneous firm quality across IPO cycles. Finally, we demonstrate that lagged IPO proceeds are related to future sectorwide asset growth and to capacity utilization. These results collectively suggest that REIT IPO cycles are driven by the demand for investment capital rather than adverse selection.

The organization of the remainder of this study is as follows. The next section briefly overviews the relevant literature. The third section presents our data and our interpretation of it. The final section contains our conclusions.

\section{IPO Literature}

\section{Theoretical Arguments}

The theoretical and empirical IPO literature contains a variety of conflicting results. ${ }^{5}$ The theoretical predictions most relevant to our research concern the quality of firms that issue equity during a "hot" IPO market. Hot IPO markets are generally characterized by a high volume of offerings, more initial-day underpricing and greater oversubscription. From one viewpoint, during hot markets issuers will attempt to exploit their informational advantage by timing their IPOs to take advantage of the market's overvaluation of their assets. An early example of this approach is Rock (1986). Rock's adverse-selection model features informed and uninformed investors competing for IPO shares. Uninformed investors do not know if issues are over- or underpriced and thus anticipate receiving shares when they are the least desirable. IPO underpricing thus arises as compensation for this winner'scurse phenomenon. A closely related view of underpricing and performance is through the lemons paradigm: Only issuers of poor quality will be willing to sell for the average price.

In contrast, several theoretical arguments assert that hot-market IPOs are not necessarily worse than cold-market IPOs. One argument is that hot markets result from positive productivity shocks to an

\footnotetext{
${ }^{5}$ Our discussion of the extensive literature on IPOs is very brief; see, for example, Ibbotson and Ritter (1995) for an overview.
} 
industry and predicts that, due to the availability of positive net present value projects, firms that do an IPO during a hot market will have good long-term performance (Allen and Faulhaber 1989, Welch 1989, Chemmanur and Fulghieri 1999). There is an empirical link between aggregate IPO volume and aggregate capital investment suggesting that favorable investment opportunities in a given sector can generate higher levels of IPO activity. Choe, Masulis and Nanda (1993) show that the adverse-selection effect is lower during expansionary market phases. Jovanovic and Rousseau (2003) establish a similar result using aggregate investment and equity issuance. Welch (1992) develops a theoretical model showing that demand elasticity can lead issuers to underprice their offering. Another viewpoint is that hot IPO markets result from random statistical fluctuations in pricing, which encourage higher quality firms to issue equity (Lucas and McDonald 1990, Stoughton, Wong and Zechner 2001).

\section{Empirical Results}

The empirical evidence on IPOs is voluminous. In particular, the issue of initial day underpricing of equities has been well documented, as early as Logue (1973). Subsequent research has detailed underpricing in markets throughout the world; Loughran, Ritter and Rydqvist (1994) summarize these results. The analysis of the long-run performance of firms following an IPO is more controversial. Recent evidence on the hypothesis that firms issuing during a hot IPO market are of poor quality has been mixed (e.g., Loughran and Ritter 1995, Spiess and Affleck-Graves 1995). Niehaus and Roth (1999) and Sherman (1999) provide empirical support for the notion that managers strategically time equity issuance in anticipation of future performance declines. This empirical fact has also been shown in the aggregate. Baker and Wurgler (2000) demonstrate that stock market returns are low in periods following a high volume of equity issuance. Schultz (2003) analyzes the market timing behavior of issuers and shows that, even assuming market efficiency, median performance after the IPO is significantly negative. Conversely, Helwege and Liang (2004), analyzing industrial IPOs from 1975 to 2000 , find no evidence of differences in the quality of firms that issue in a hot versus cold market. Gompers and Lerner (2003) analyze the long-term (up to 5 years) performance of 3,661 IPOs over the pre-NASDAQ period, 1935 to 1972, and also find no evidence of long-term abnormal returns. ${ }^{6}$

\section{REIT IPOS}

The REIT market has undergone numerous structural changes since its inception in 1960. REITs formed during the 1960s and 1970s were mostly engaged in higher risk development and construction

\footnotetext{
${ }^{6}$ See also Brav and Gompers (1997), who find no evidence of abnormal IPO operating performance.
} 
loans, and were ill positioned to withstand the real estate crash of the mid-1970s. REITs created in the 1980s were basically passive, diversified holdings of real estate. Most were finite-horizon REITs, which limited their growth potential. This market structure changed dramatically in the 1990s. The new REITs featured active management, low leverage, infinite lives and substantial insider holdings (often more than a third of the outstanding shares). These changes led to greater institutional ownership, as documented in Ling and Ryngaert (1997). For the pre-1990 REITs, institutional shareholders usually held less than $10 \%$ of the outstanding shares one quarter after the IPO. The corresponding figure for the post-1990 REITs is 42\%. In 1992, REITs also began to use the umbrella partnership REIT (UPREIT) form of organization, which allowed them to combine partnerships without adverse tax consequences. This form rapidly became used in the majority of REIT IPOs. As Ling and Ryngaert point out, the UPREIT structure caused greater uncertainty in REIT valuation because of its increased potential for conflicts of interest.

There is evidence that these time series trends in REITs have affected their IPO patterns. As mentioned above, Wang, Chan and Gau (1992) find that over the 1971 to 1988 period, REIT IPOs suffered a price decline on the first day of trading and negative abnormal stock market performance in the subsequent 4 months. They attribute this result to the inapplicability of the adverseselection/winner's-curse theories due to the relative absence of institutional investors (the model's informed investors) in REIT IPOs over their study period. ${ }^{7}$ Conversely, over the period 1991 to 1994, Ling and Ryngaert (1997) find that REIT IPOs are underpriced; they attribute this finding to greater institutional investor participation in the REIT IPO market over time. ${ }^{8}$

While these results imply that information asymmetry across investors in REITs has increased over time, it leaves open the question of whether the information advantage that REIT managers possess drives IPO cycles in the industry. Buttimer, Hyland and Sanders (2005) analyze the long-run stock price behavior of REIT IPOs. ${ }^{9}$ They find that the stock price performance of REIT IPOs is the same in cold and hot markets, using high IPO volume as the definition of hot markets. They conclude that the demand for capital (rather than information asymmetry or investor sentiment) explains much of the time series variation in IPO cycles. In the next section, we present our tests, which directly explore the

\footnotetext{
${ }^{7}$ For evidence that REITs' seasoned equity offerings (SEOs) are different than those of regular corporations, see Ghosh, Nag and Sirmans (1998), Ghosh, Sirmans and Nag (1999) and Friday, Howton and Howton (2000). ${ }^{8}$ Ljungqvist and Wilhelm (2003) analyze the influence of ownership structure on IPO pricing during the dot.com bubble.

${ }^{9}$ An earlier version of this article, Hartzell et al. (2003), included an analysis of longterm stock-price performance using a different methodology than Buttimer, Hyland and Sanders (2005) and obtained results consistent with theirs.
} 
link between the underlying real markets and IPO cycles, as well as the differences in operating performance as a function of hot and cold IPO markets. As we show below, our results are consistent with those of Buttimer, Hyland and Sanders; we find a link between IPO cycles and underlying real asset (real estate) markets and no difference in operating performance between firms that go public during hot and cold markets.

\section{Data Set and Statistical Analysis}

\section{Data Sources}

We collected information on each REIT IPO over the 1980 to 1998 period, including the IPO date, offer price and number of shares offered, from various issues of the Investment Dealer's Digest and the Securities Data Corporation (SDC) database. We match these data with data from the Center for Research in Security Prices (CRSP) and Compustat in order to calculate initial-day returns (Day 0 Return) and various operating performance variables; we include in the sample every REIT IPO for which we can obtain both the offer price and initial-day closing price.

We use several measures of the relative strength of both the underlying real asset market and the REIT market. First, as proxies for current yield in the commercial property market, we use the quarterly returns per the National Council of Real Estate Investment Fiduciaries (NCREIF's) index (NCREIF Return) and the return on equity (ROE) from direct investment in commercial properties from the American Council of Life Insurers (ACLI) Investment Bulletin: Mortgage Commitments on Multifamily and Nonresidential Properties. ${ }^{10} \mathrm{ACLI}$ bases their data on both cap rates and transactions prices. Second, to capture marketwide vacancy rates, we use the summary vacancy rate as calculated by Torto-Wheaton (Vacancy). Third, we also use the space market index (SMI) as a measure of macro real market performance (see Miles 1997 and Miles and Guilkey 1998). Prior to the development of the SMI, analysts and researchers typically used vacancy rates to evaluate aggregate real estate market conditions, but these rates proved to be excessively sticky. The SMI solves this problem; it measures the

\footnotetext{
${ }^{10}$ This ACLI Bulletin reports data on the loan-to-value ratio (LTVR), the mortgage constant (= debt service $\div$ loan amount), and the capitalization rate (= net operating income $\div$ value of the property). ROE is imputed using the formula Capitalization rate $=$ LTVR $\times$ Mortgage constant $+(1-L T V R) \times R O E$. This uses the band of investment technique common among practitioners, rather than the full Ellwood formulation because it appears to fit well in practice (e.g., see $\mathrm{http}: / /$ www.mass.gov/dpl/boards/re/contedu/2001/029.htm), and because the simple version eliminates the need to make several assumptions.
} 
change in employment (demand) relative to the change in stock ratio (supply). ${ }^{11}$ This comparison is relative to its own long-term average using a 3-year rolling measure ( 2 years of history and 1 year of forecasts). An SMI value greater than one implies an above-average climate for real estate performance, that is, demand is greater than supply.

To measure the demand for REITs, we use the dividend yield for the aggregate REIT industry from NAREIT, labeled DivYield. REIT analysts frequently use the ROE on direct property investment as a proxy for cash inflows to REITs and compare it to the dividend yield on REITs, which represents cash outflows to REIT shareholders. Finally, because dividend yields are likely to be affected both by REIT prices and by the performance of the underlying assets, we use the level of the NAREIT Index (REIT Price Index) as a more direct measure of REIT pricing. Since our purpose is to measure the absolute conditions in the real asset markets rather than relative to the stock markets, we do not adjust these REIT variables for the condition of the overall market.

When underlying real asset markets are hot, we would expect high returns on the equity of commercial property (high NCREIF Return and ROE), high occupancy rates (low Vacancy) and a high demand relative to supply (high SMI). Similarly, when REITs are especially attractive to the market, we would expect low dividend requirements by investors relative to their valuations (low DivYield) and higher overall REIT prices (high REIT Price Index).

We use two different characterizations of hot and cold markets. The first is a supply-side definition: the number of IPOs in each quarter. The second is a demand-side definition: the valueweighted average initial-day return for the quarter. As we will see in the following correlation analysis, the two measures are only weakly positively correlated. As such, we conduct our tests using both the supply- and demand-based definitions.

\footnotetext{
${ }^{11}$ Stock here is the number of total square feet. The data on the total square feet are obtained from F.W. Dodge through a subscription-based service. F.W. Dodge provides forecasts of future supply in addition to historical data.
} 
Figure 1 a Supply and demand definitions of hot and cold REIT IPO markets. This figure presents the number of IPOs and initial-day returns for REIT IPOs over the 1980 to 1998 period. Day 0 Return is the weighted-average return on the day of the IPO, relative to the offer price. Both the number of IPOs and Day 0 Return are calculated on a quarterly basis.

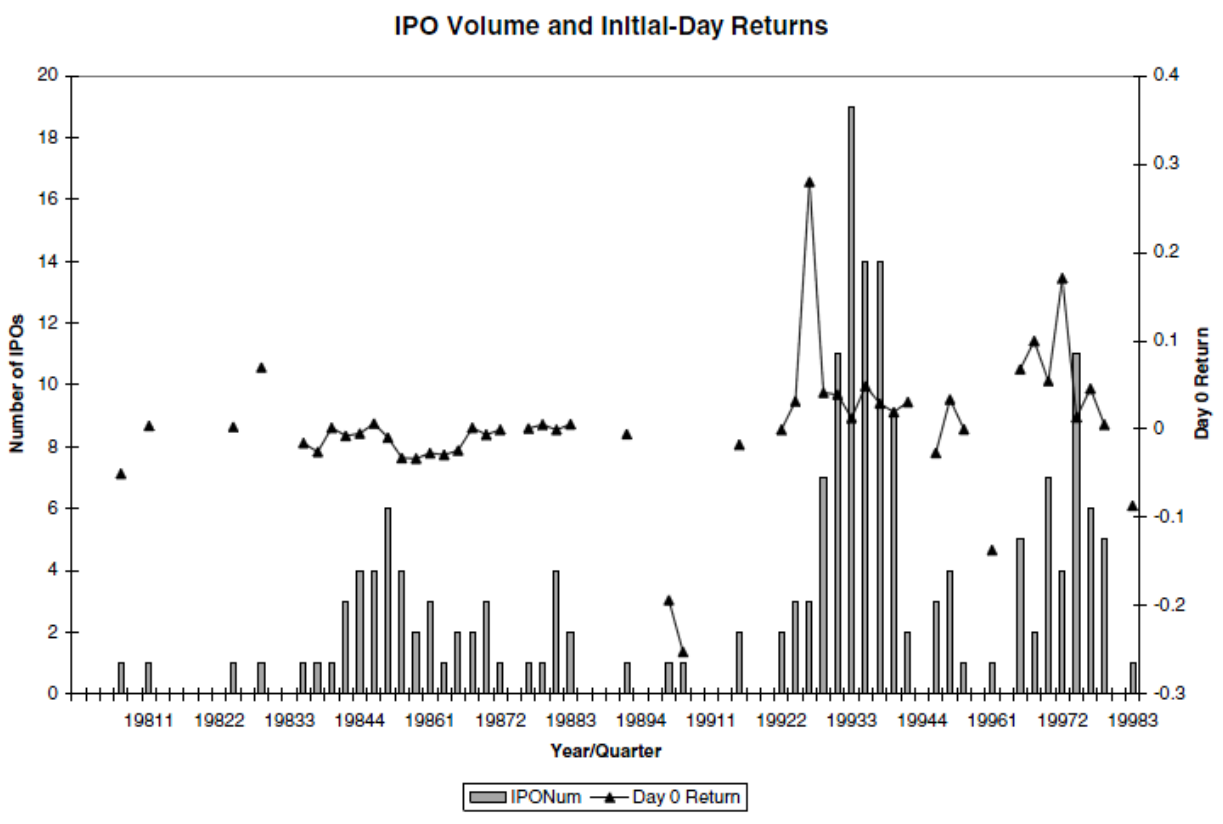

Summary Statistics

Figure 1 shows our two measures of the heat of the REIT IPO market during the two decades of our sample time frame, as broken into quarters. ${ }^{12}$ There are pronounced IPO waves from 1985 to 1988 and from 1992 to 1995. The first cycle was coincident with the Tax Reform Act of 1986, and the second was arguably accelerated by changes in REIT organizational form. These facts should be considered when interpreting results relating to IPO cycles. While our interest is in testing the impact of the underlying real markets on IPOs, REIT IPO waves may also stem from regulatory shifts as well as the underlying characteristics of real markets, the demand for future capital and other fundamental economic factors.

The basic statistics for our sample are given in Table 1. The data are calculated on a quarterly basis, either by directly observing quarterly numbers, or by calculating the time series average for the period (for ROE, NCREIF Return, Vacancy, DivYield, SMI and REIT Price Index), or by taking a value-

\footnotetext{
${ }^{12}$ We obtain very similar results if we use semiannual rather than quarterly data. In addition, we reestimated our tables excluding the extreme $2 \%$ of observations ( $1 \%$ in each tail), and obtain very similar results. As a further robustness check, we reestimated each of the following tables separately for the 1980s and 1990s. Again, this change has no substantive effect on our results.
} 
weighted average across all IPOs in that period (Day 0 Return). IPONum is the number of IPOs in each period.

Table 1 a Summary statistics.

\begin{tabular}{llccccc}
\hline \hline Variable & $\begin{array}{l}\text { Number of } \\
\text { Observations }\end{array}$ & Mean & Median & $\begin{array}{l}\text { Standard } \\
\text { Deviation }\end{array}$ & Minimum & Maximum \\
\hline Day O Return & 49 & $0.27 \%$ & $0.15 \%$ & $7.62 \%$ & $-25.21 \%$ & $28.00 \%$ \\
IPONum & 76 & 2.5 & 1.0 & 3.7 & 0.0 & 19.0 \\
NCREIF Return & 75 & $2.04 \%$ & $2.08 \%$ & $1.77 \%$ & $-5.33 \%$ & $5.54 \%$ \\
Vacancy & 76 & $14.14 \%$ & $15.30 \%$ & $4.67 \%$ & $4.20 \%$ & $19.20 \%$ \\
ROE & 76 & $7.40 \%$ & $7.20 \%$ & $1.70 \%$ & $3.60 \%$ & $10.60 \%$ \\
Apt SMI & 76 & 1.07 & 0.58 & 1.17 & -0.11 & 4.09 \\
Ofc SMI & 76 & 0.97 & 0.38 & 1.27 & -0.06 & 4.38 \\
Rtl SMI & 76 & 0.93 & 0.95 & 0.62 & -0.10 & 2.36 \\
Ind SMI & 76 & 1.05 & 0.93 & 0.84 & -0.11 & 2.81 \\
DivYield & 76 & $7.66 \%$ & $7.70 \%$ & $0.94 \%$ & $5.50 \%$ & $10.50 \%$ \\
REIT Price Index & 76 & 90.7 & 90.2 & 16.5 & 59.1 & 120.2 \\
\hline
\end{tabular}

Notes: This table presents time-series summary statistics for the REIT IPOs over the 1980 to 1998 period. All variables are calculated on a quarterly basis. Day O Return is the value-weighted average initial-day return of IPOs over that period, where the initial-day return is calculated relative to the offer price. This variable is only tabulated for periods with at least one IPO. IPONum is the number of REIT IPOs in each quarter. NCREIF Return is the return on the NCREIF index. Vacancy is a summary vacancy rate as calculated by Torto-Wheaton. ROE is the return on equity associated with direct investment in commercial property from the American Council of Life Insurers. Apt SMI, Ofc SMI, Rtl SMI and Ind SMI are space market indices for apartment, office, retail and industrial properties, respectively. These are as developed by Miles (1997) and Miles and Guilkey (1998), and measure demand for real estate relative to supply. DivYield is the dividend yield for the aggregate REIT industry per NAREIT. REIT Price Index is the level of the NAREIT price index for all REITs.

The IPOs in this data set have slightly positive average initial-day returns, but the returns are insignificantly different from zero over the whole sample. However, as is evident from the previous literature on REIT IPOs, this is due to the original period of overpricing up to 1990 and the subsequent underpricing. The average number of REIT IPOs over this period is 2.5 per quarter. Table 1 also presents our measures of real market performance during this period. The real markets over this period exhibited moderate growth. An index of appraised value appreciation (the NCREIF index) returned $2.04 \%$ per quarter. The average (annualized) return on direct real estate investment $(R O E)$ was $7.4 \%$, which is approximately equal to the mean (annualized) REIT dividend payout (7.66\%). The measure of aggregate vacancy rates averaged $14.14 \%$ over this period. The $S M I$ indices for retail and office each averaged less than 1 in this period, indicating that, on average, supply exceeded demand. Conversely, the $S M I$ indices for apartments and industrials were greater than 1, suggesting that, on average for these sectors, demand exceeded supply. 
Table 2 shows the correlations between Day 0 Return, REIT IPO volume and our nine measures of real estate and REIT performance. The correlations are contemporaneous; given the strong positive autocorrelation in the performance measures, the results using lags are qualitatively very similar. ${ }^{13}$ Contemporaneous variables are also used in the following analysis in order to maximize the number of data points available. The initial-day return is significantly positively correlated $(0.271)$ to $R O E$ and to the REIT Price Index (0.322); it is strongly and negatively correlated $(-0.693)$ to the dividend yield. There is also a positive and significant correlation (0.251) between IPO volume and IPO initial-day return, which suggests that our two characterizations of hot and cold markets are positively related, but are clearly capturing different phenomena. The volume of IPOs is also significantly positively related to $R O E$, to the REIT Price Index and to each of our SMI indices. The volume of IPOs is also highly negatively correlated (0.521 ) with dividend yield. These results are consistent with conditions in the underlying real asset markets influencing a REIT's decision to do an IPO. We next examine these relations more formally.

\section{Hot and Cold IPO Markets as Functions of Underlying Real Asset Markets}

One of the key theoretical predictions open to debate relates to the quality of the firms that conduct IPOs in hot versus cold markets. As noted earlier, neither the theory nor the empirical work consistently predicts whether hot markets are more often associated with good or bad firms issuing equity. Like several other studies, we find increased REIT IPO activity after periods of high initial-day returns. ${ }^{14}$ While, as noted above, the contemporaneous correlation between REIT IPO volume and initial-day return is 0.251 in our sample, the correlation between REIT IPO volume and the previous quarter's initial-day return is 0.410 .

As Table 2 shows, our seven measures of real market performance are often highly correlated. In the subsequent analysis, rather than relying on each of these proxies individually, we use a common factor extracted from the seven indices that captures the overall condition of the real asset market each quarter. Specifically, we use ROE and NCREIF returns, vacancy rates and the space market indices for the four property types. From these seven variables, we extract the first principal component as a measure

\footnotetext{
${ }^{13}$ The issue of lead-lag relations between securitized and unsecuritized real estate has been the topic of significant research with somewhat varying conclusions. A positive, lagged relation between securitized and unsecuritized real estate, with securitized returns leading unsecuritized returns or cap rates, is found in Gyourko and Keim (1993), Fisher, Geltner and Webb (1994), Barkham and Geltner (1995) and Geltner and Goetzmann (2000). Conversely, Liu and Mei (1992) find that REIT returns can be predicted by capitalization rates based on actual transaction prices.

${ }^{14}$ For example, see Ibbotson and Jaffe (1975), Ibbotson, Sindelar and Ritter (1994) and Lowry and Schwert (2002). Lowry and Schwert focus on the drivers of IPO cycles. They show that the positive relation between initial-day underpricing and subsequent IPO volume is related to information learned during the registration period.
} 
of the broad time-varying conditions in the real asset market. Table 3 summarizes this procedure. This first component explains $51 \%$ of the variance in the variables. Furthermore, this variable has significant intuitive appeal; ROE, NCREIF Return and the SMIs enter positively, while vacancy rates enter negatively. ${ }^{15}$ In the remaining analysis, this variable (which we label Underlying Mkt Factor) is our newproxy for the state of the underlying real asset market. Figure 2 presents this variable and dividend yield over our sample period. This diagram shows the relatively poor performance of the underlying real asset factor over the interval 1986 to 1992 and its relatively strong performance in the last 5 years of our sample interval.

Table 2 a Correlation matrix.

\begin{tabular}{|c|c|c|c|c|c|c|c|c|c|c|}
\hline & Day 0 Return & IPONum & NCREIF Return & Vacancy & $R O E$ & Apt SMI & Ofc SMI & Rtl SMI & Ind SMI & DivYield \\
\hline Day 0 Return & 1 & & & & & & & & & \\
\hline IPONum & $\begin{array}{l}0.251^{*} \\
(0.08)\end{array}$ & 1 & & & & & & & & \\
\hline NCREIF Return & $\begin{array}{r}0.114 \\
(0.44)\end{array}$ & $\begin{array}{r}-0.083 \\
(0.48)\end{array}$ & 1 & & & & & & & \\
\hline Vacancy & $\begin{array}{r}-0.129 \\
(0.38)\end{array}$ & $\begin{array}{r}0.125 \\
(0.28)\end{array}$ & $\begin{array}{c}-0.633^{* * *} \\
(0.00)\end{array}$ & 1 & & & & & & \\
\hline$R O E$ & $\begin{array}{l}0.271^{*} \\
(0.06)\end{array}$ & $\begin{array}{l}0.299^{* * *} \\
(0.01)^{2}\end{array}$ & $\begin{array}{r}0.190 \\
(0.10)\end{array}$ & $\begin{array}{c}-0.600^{* * * *} \\
(0.00)\end{array}$ & 1 & & & & & \\
\hline Apt SMI & $\begin{array}{r}0.143 \\
(0.33)\end{array}$ & $\begin{array}{l}0.365^{* * *} \\
(0.00)\end{array}$ & $\begin{array}{c}0.172 \\
(0.14)\end{array}$ & $\begin{array}{r}-0.115 \\
(0.32)\end{array}$ & $\begin{array}{l}0.441^{* * *} \\
(0.00)\end{array}$ & 1 & & & & \\
\hline$O f c S M I$ & $\begin{array}{r}0.121 \\
(0.41)\end{array}$ & $\begin{array}{c}0.223^{*} \\
(0.05)\end{array}$ & $\begin{array}{r}0.160 \\
(0.17)\end{array}$ & $\begin{array}{r}-0.164 \\
(0.16)\end{array}$ & $\begin{array}{l}0.491^{* * *} \\
(0.00)\end{array}$ & $\begin{array}{l}0.970^{* * *} \\
(0.00)\end{array}$ & 1 & & & \\
\hline Rtl SMI & $\begin{array}{r}-0.022 \\
(0.88)\end{array}$ & $\begin{array}{l}0.243^{* *} \\
(0.03)\end{array}$ & $\begin{array}{l}0.468^{* * *} \\
(0.00)\end{array}$ & $\begin{array}{r}-0.036 \\
(0.76)\end{array}$ & $\begin{array}{c}-0.109 \\
(0.35)\end{array}$ & $\begin{array}{l}0.505^{* * * *} \\
(0.00)\end{array}$ & $\begin{array}{l}0.411^{* * * *} \\
(0.00)\end{array}$ & 1 & & \\
\hline Ind SMI & $\begin{array}{r}0.103 \\
(0.48)\end{array}$ & $\begin{array}{l}0.404^{* * *} \\
(0.00)\end{array}$ & $\begin{array}{l}0.255^{* *} \\
(0.03)\end{array}$ & $\begin{array}{r}-0.003 \\
(0.98)\end{array}$ & $\begin{array}{l}0.247^{* *} \\
(0.03)\end{array}$ & $\begin{array}{l}0.936^{* * *} \\
(0.00)\end{array}$ & $\begin{array}{l}0.874^{* * * *} \\
(0.00)\end{array}$ & $\begin{array}{l}0.746^{* * *} \\
(0.00)\end{array}$ & 1 & \\
\hline DivYield & $\begin{array}{c}-0.693^{* * *} \\
(0.00)\end{array}$ & $\begin{array}{c}-0.521^{* * *} \\
(0.00)\end{array}$ & $\begin{array}{r}-0.181 \\
(0.12)\end{array}$ & $\begin{array}{r}0.103 \\
(0.37)\end{array}$ & $\begin{array}{c}-0.465^{* * *} \\
(0.00)\end{array}$ & $\begin{array}{c}-0.404^{* * *} \\
(0.00)\end{array}$ & $\begin{array}{c}-0.404^{* * *} \\
(0.00)\end{array}$ & $\begin{array}{c}-0.252^{* *} \\
(0.03)\end{array}$ & $\begin{array}{c}-0.393^{* * *} \\
(0.00)\end{array}$ & 1 \\
\hline REIT Price Index & $\begin{array}{l}0.322^{* *} \\
(0.02)\end{array}$ & $\begin{array}{c}0.202^{*} \\
(0.08)\end{array}$ & $\begin{array}{l}0.381^{\text {**** }} \\
(0.00)\end{array}$ & $\begin{array}{r}0.059 \\
(0.61)\end{array}$ & $\begin{array}{c}-0.110 \\
(0.35)\end{array}$ & $\begin{array}{r}0.115 \\
(0.32)\end{array}$ & $\begin{array}{r}0.070 \\
(0.55)\end{array}$ & $\begin{array}{l}0.608^{* * *} \\
(0.00)\end{array}$ & $\begin{array}{l}0.351^{\text {**** }} \\
(0.00)\end{array}$ & $\begin{array}{c}-0.542^{* * *} \\
(0.00)\end{array}$ \\
\hline
\end{tabular}

Notes: This table presents Pearson correlation coefficients for a sample of REIT IPOs over the 1980 to 1998 period. All variables are calculated on a quarterly basis. Variables are as defined in Table 1. $p$ values for each coefficient are in parentheses. ${ }^{*},{ }^{* *}$ and ${ }^{* * *}$ denote significance at the $0.10,0.05$ and 0.01 levels, respectively.

We conduct our first set of regressions with two key explanatory variables: the underlying real asset market variable (which relies on several measures of the market) and the dividend yield. By using these two, we are able to test whether or not the "heat" of the REIT IPO market is a function of the underlying real markets and of relative REIT prices. Table 4 shows the results of a Poisson regression using the number of REIT IPOs in a given quarter as the dependent variable. ${ }^{16}$ Regression (1) shows that our underlying real market factor has a positive and significant association with IPO volume. This suggests that strong underlying real market conditions (a high underlying factor via low vacancy rates and high SMIs, for example) can help increase IPO volumes.

\footnotetext{
${ }^{15}$ Gallagher and Wood (1999) show that the SMI is a very useful way to assess the risk of overbuilding. In addition, our factor includes vacancies, which mitigates potential distortion in the SMI caused by high vacancy rates.

${ }^{16}$ We obtain similar results using probit analysis and a dichotomous characterization of hot and cold markets.
} 
Table 3 - Principal components analysis of underlying real estate market variables.

\begin{tabular}{lllll}
\hline \hline \multicolumn{2}{l}{ Panel A: Principal components } & & & \\
\hline Component & Eigenvalue & Difference & Proportion & Cumulative \\
\hline 1 & 3.57 & 1.85 & 0.51 & 0.51 \\
2 & 1.73 & 0.47 & 0.25 & 0.76 \\
3 & 1.26 & 1.03 & 0.18 & 0.94 \\
4 & 0.23 & 0.06 & 0.03 & 0.97 \\
5 & 0.17 & 0.14 & 0.02 & 0.99 \\
6 & 0.03 & 0.02 & 0.00 & 1.00 \\
7 & 0.01 & & 0.00 & 1.00 \\
\hline
\end{tabular}

Panel B: First eigenvector, Underlying Mkt Factor

\begin{tabular}{lc}
\hline Variable & Standardized Coefficient \\
\hline NCREIF Return & 0.237 \\
Vacancy & -0.171 \\
ROE & 0.262 \\
Apt SMI & 0.497 \\
Ofc SMI & 0.484 \\
Rtl SMI & 0.349 \\
Ind SMI & 0.493 \\
\hline
\end{tabular}

Notes: This table presents principal components analysis for seven variables measuring the conditions in the underlying real estate market. These variables are NCREIF Return, Vacancy, ROE, Apt SMI, OfC SMI, Rt SMI and Ind SMI; all are as defined in Table 1 and are calculated on a quarterly basis over the 1980 to 1998 period. Panel A presents the seven components of the variance-covariance matrix, their eigenvalues, the difference between each eigenvalue and the next smallest, the proportion of the variance that each component accounts for and the cumulative variance explained. Panel B presents the coefficients for each variable used to construct the first component, labeled Underlying Mkt Factor, where each contributing variable is standardized into a mean of zero and standard deviation of one.

As expected, Regressions (2) and (3) show that dividend yield has a strong negative relation with IPO volume. An important aspect of Regression (3) is that even with dividend yield as an independent variable, our underlying real market factor has a positive and significant sign. One influence on dividend yield is the performance of the REIT stock market, in addition to any influence of the underlying real asset market. In an attempt to disentangle these two components, Regression (4) uses the level of REIT prices in place of dividend yield. When this switch is made, our underlying market factor regains much of its economic and statistical significance in explaining IPO volume. This is consistent with dividend yield containing a component that is a function of the underlying real market rather than just stock market effects. It is also worth noting that we are not making claims as to the sources of the effect of REIT prices on IPO activity. For example, it could be that the variation in pricing is due to rational time variation in investors' preferences for REITs, or to pricing fluctuations that are not necessarily related to fundamentals, as explored by Ljungqvist, Nanda and Singh (2003). 
Figure 2 Underlying real asset market and REIT market conditions. This figure presents proxies for the condition of the underlying real asset markets and for the relative price of REITs over the 1980 to 1998 period. Underlying Mkt Factor is the first principal component from a set of seven variables measuring the performance of the real asset market, and is as defined in Table 3. DivYield measures the price of REITs relative to their dividends as defined in Table 1 . Both are calculated on a quarterly basis.

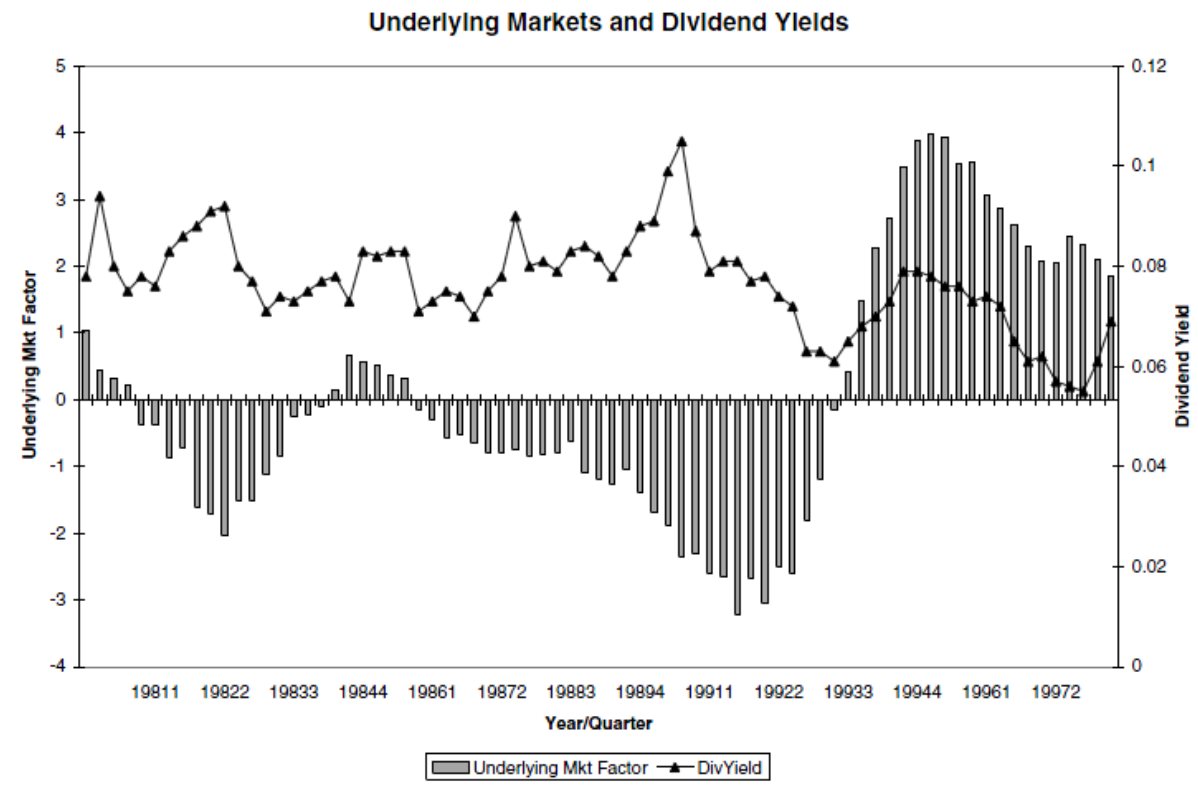

The evidence in Table 4 is consistent with both the conditions of the underlying real asset market and relative REIT prices driving REITs' decisions to go public. Specifically, REIT IPO volume is increasing in the heat of the underlying real estate markets and in the level of REIT prices. These two effects appear to be independent of each other, and both seem to be incorporated to some extent into REITs' dividend yield (i.e., this variable appears to contain both an underlying market component and a more pure REIT price component).

Table 5 repeats this analysis using OLS regression on our demand-side characterization of a hot market: its weighted-average, initial-day return (Day 0 Return). The results for dividend yield are similar; times of low dividend yields and high REIT prices are significantly associated with greater demand for REIT IPOs (see Regressions (2), (3) and (4)). However, we find no significant relation between the Underlying Mkt Factor and Day 0 Return, whether the market variable is included alone in Regression (1), together with dividend yield or REIT prices in Regressions (3) and (4). ${ }^{17}$

\footnotetext{
${ }^{17}$ As a robustness check, we also ran these regressions using the portion of dividend yield that is orthogonal to our underlying market factor, and we find similar results.
} 
Table 4 घ Poisson models of hot/cold REIT IPO market as function of underlying real estate and REIT markets: Supply-side definition.

\begin{tabular}{lcccc}
\hline \hline & \multicolumn{3}{l}{ IPONum } \\
\cline { 2 - 5 } Dependent Variable & $(1)$ & $(2)$ & $(3)$ & $(4)$ \\
\hline Underlying Mkt Factor & $0.24^{* * *}$ & & $0.10^{* *}$ & $0.23^{* * *}$ \\
DivYield & $(6.52)$ & & $(2.19)$ & $(6.01)$ \\
& & $-82.70^{* * *}$ & $-73.94^{* * *}$ & \\
REIT Price Index & & $(-10.54)$ & $(-8.58)$ & $0.014^{* * *}$ \\
Constant & & & $(4.06)$ \\
Number of observations & $(10.13)$ & $(7.99)$ & $(10.12)$ & $(-1.15)$ \\
Pseudo $R$-squared & 0.092 & 76 & 75 & 75 \\
\end{tabular}

Notes: This table presents Poisson regressions of the number of REIT IPOs on variables measuring the underlying real estate market as well as relative REIT valuations. All variables are calculated on a quarterly basis over the 1980 to 1998 period. The dependent variable, IPONum, is the number of REIT IPOs for that quarter. Underlying Mkt Factor is the first principal component of the underlying real estate market variables, as calculated in Table 3. DivYield and REIT Price Index are as defined in Table 1. $t$ statistics for each coefficient are in parentheses. ${ }^{*},{ }^{* *}$ and ${ }^{* * *}$ denote significance at the $0.10,0.05$ and 0.01 levels, respectively. The table also presents the number of observations and the Pseudo $R$-squared for each regression.

Taken together, Tables 4 and 5 present a consistent role for dividend yield and REIT prices in explaining both our supply-side measure of the IPO market (IPO volume) and demand-side measure (initial-day returns). The underlying market factor is significantly related to the supply-side variable, but not the demand-side variable. When interpreting these results, it is worth noting that there are some significant differences in the demand- and supply-side definitions of the IPO market. First, while the supply-side definition is one that captures an ex ante perception of some market participants (i.e., REIT IPO issuers), the demand-side definition is an ex post measure. Second, because it is affected by other motivations for underpricing, the demand-side measure is also subject to different effects, such as time variation in asymmetric information (e.g., Ling and Ryngaert 1997) or time variation in the desire to signal firm quality in order to raise equity in the future. This latter motivation may be especially applicable to REITs due to their required dividend payout and resulting frequent need to raise external capital. Third, by its nature, we are unable to observe the demand-side variable for quarters in which there are no IPOs; thus, this measure ignores information in some periods. 
Table 5 - OLS models of hot/cold REIT IPO market as a function of underlying real estate and REIT markets: Demand-side definition.

\begin{tabular}{lcccc}
\hline \hline \multicolumn{4}{l}{ Day 0 Return } & \\
\cline { 2 - 5 } Dependent Variable & $(1)$ & $(2)$ & $(3)$ & $(4)$ \\
\hline Underlying Mkt Factor & 0.007 & & -0.005 & 0.01 \\
DivYield & $(1.22)$ & & $(-1.03)$ & $(0.85)$ \\
REIT Price Index & & $-5.46^{* * *}$ & $-5.84^{* * *}$ & \\
Constant & & $(-6.58)$ & $(-6.62)$ & $0.001^{* *}$ \\
Number of observations & 48 & & & $(2.08)$ \\
Adjusted $R$-squared & 0.00 & $0.41^{* * *}$ & $0.44^{* * *}$ & $-0.13^{* *}$ \\
\hline
\end{tabular}

Notes: This table presents ordinary least squares (OLS) regressions of REIT IPO initial-day returns on variables measuring the underlying real estate market. All variables are calculated on a quarterly basis over the 1980 to 1998 period. The dependent variable, Day 0 Return, is the weighted-average intial-day return for the period, and is only calculated for periods containing at least one REIT IPO. Independent variables are as defined in Tables 1 and 3. $t$ statistics for each coefficient are in parentheses. *, ${ }^{* *}$ and ${ }^{* * *}$ denote significance at the $0.10,0.05$ and 0.01 levels, respectively. The table also presents the number of observations and the adjusted $R$-squared for each regression.

Post-IPO Operating Performance Across Hot and Cold Markets

While the previous tests establish a link between underlying real estate markets, REIT pricing and IPO markets, they do not present direct evidence on the variation in the quality of firms going public over the IPO cycle. To address this issue more precisely, we now examine post-IPO operating performance. If adverse selection is a significant explanation of firm quality over the cycle, then we would expect to see low-quality firms taking advantage of hot markets as the optimal time to go public when pricing is favorable. This would imply that hot-market IPOs would exhibit worse subsequent operating performance. Alternatively, if positive productivity shocks (increased demand for investment capital) are an important determinant of REIT IPO cycles, then we would not expect to see cold-market firms outperform their hot-market counterparts.

Table 6 presents an analysis of two measures of abnormal operating returns. Because we want to test whether new REITs that come out during hot markets perform differently than those that come out during cold markets, we adjust each measure of operating performance by subtracting the median performance of all REITs. These industry-adjusted performance measures should be better able to detect abnormal performance in post-IPO, young REITs, and prevent us from improperly attributing sectorwide performance to the state of the IPO market. Specifically, Adjusted ROA is the REIT's return on 
book assets (operating income for the given quarter divided by the initial book value of total assets) less the median $R O A$ ratio for all REITs on Compustat. Adjusted $R O E_{m k t}$ is similarly constructed, but with operating income scaled by the market value of equity. We conduct our regressions using the 12 fiscal quarters after each sample firm's IPO. Because each firm contributes up to 12 observations, the standard errors are calculated such that they are robust to clustering (i.e., lack of independence) within each firm over time.

Table 6 - OLS models of operating performance as a function of hot/cold REIT IPO market.

\begin{tabular}{lcccc}
\hline \hline Dependent Variable & $\begin{array}{l}\text { Adjusted ROA } \\
(1)\end{array}$ & $\begin{array}{l}\text { Adjusted ROA } \\
(2)\end{array}$ & $\begin{array}{l}\text { Adjusted ROE } \\
(3)\end{array}$ & $\begin{array}{l}\text { Adjusted ROE } \\
(4)\end{array}$ \\
\hline IPONum & 0.000001 & & 0.0002 & \\
& $(0.01)$ & -0.004 & $(0.75)$ & 0.084 \\
Day 0 Return & & $(-0.33)$ & & $(0.74)$ \\
& & 0.001 & 0.001 & 0.002 \\
UPREIT & 0.001 & $(0.62)$ & $(0.33)$ & $(0.35)$ \\
& $(0.61)$ & $0.004^{* * *}$ & 0.008 & 0.006 \\
SelfAdmin & $0.004^{* * *}$ & $(2.75)$ & $(1.50)$ & $(1.12)$ \\
& $(2.83)$ & $0.003^{*}$ & 0.007 & 0.006 \\
Mortgage & $0.003^{*}$ & $(1.91)$ & $(0.92)$ & $(0.91)$ \\
& $(1.90)$ & $-0.020^{* * *}$ & $-0.024^{* * *}$ & $-0.022^{* * *}$ \\
BookLeverage & $-0.020^{* * *}$ & $(-10.78)$ & $(-3.10)$ & $(-3.44)$ \\
& $(-10.82)$ & 0.0002 & 0.0009 & 0.00003 \\
Ln(TotalAssets) & 0.0001 & $(0.54)$ & $(0.77)$ & $(0.02)$ \\
& $(0.41)$ & $0.006^{* * *}$ & -0.005 & -0.0003 \\
Constant & $0.006^{* * *}$ & $(3.07)$ & $(-0.66)$ & $(-0.05)$ \\
& $(3.19)$ & 2,021 & 2,017 & 2,017 \\
Number of observations & 2,021 & 0.148 & 0.010 & 0.013 \\
Adjusted $R$-squared & 0.148 & & & \\
\hline
\end{tabular}

Notes: This table presents ordinary least squares (OLS) regressions of REIT operating performance on variables measuring hot REIT IPO markets and control variables. All variables are calculated on a quarterly basis. The regressions include up to 12 quarters following REIT IPOs that occurred over the 1980 to 1998 period. In columns 1 and 2, the dependent variable, Adjusted $R O A$, equals operating income scaled by total assets, less the median of all REITs for that quarter. In columns 3 and 4 , the dependent variable, Adjusted $R O E_{m k t}$, equals operating income scaled by the market value of equity, less the median of all REITs for that quarter. IPONum and Day 0 Return are measures of the supply- and demand-side definitions of hot IPO markets, respectively, and are as defined in Table 1. These take the appropriate value depending on the time when the REIT went public. UPREIT, SelfAdmin and Mortgage are indicator variables for whether the REIT in question is an UPREIT, is self-administered or is a mortgage REIT, respectively. BookLeverage is defined as the ratio of total liabilities to total assets, and Ln(TotalAssets) is a proxy for size, equal to the natural logarithm of total assets. $t$-statistics for each coefficient are in parentheses and are based on standard errors that are robust to clustering within firms over time. ${ }^{*},{ }^{* *}$ and ${ }^{* * *}$ denote significance at the $0.10,0.05$ and 0.01 levels, respectively. The table also presents the number of observations and the adjusted $R$-squared for each regression.

Each of the four regressions presented uses a set of control variables that may help explain operating performance. First, we include a dummy for UPREIT status, as UPREITs could either outperform their peers (e.g., due to better implicit pricing on acquired properties) or underperform (e.g., due to greater incentive conflicts between stockholders and unitholders). This variable has no significant relation with Adjusted ROA or ROE. Second, we include a dummy for self-administered REITs, which, due to reduced conflicts of interest, may outperform advisor REITs. Consistent with this, the self- 
administered variable has a positive and significant relation with $R O A$. Third, because the underlying expected operating returns might be different for equity and mortgage REITs, we include a dummy for mortgage REITs (which has a significant, positive effect on $R O A$ and an insignificant relation with $R O E$ ). Fourth, we control for differences in leverage that are likely to affect operating ratios by including each firm's book leverage (which has a significant, negative association with both performance variables). Finally, in order to control for potential economies of scale, we include as a size proxy the log of total assets (which is insignificant, suggesting no economies or diseconomies of scale). As expected, given the volatility inherent in market valuations, the regressions for $R O A$ fit better than regressions for $R O E$; the respective $R 2$ s average $14.8 \%$ and $1 \%$, respectively.

The most important part of these results is the analysis of the coefficients on the variables characterizing market conditions at the IPO stage. Regressions (1) and (3) include the number of IPOs in the given quarter that the firm went public (the supply-side definition), while Regressions (2) and (4) include the initial-day return as of the IPO quarter (the demand-side definition). While the coefficients on these variables in the third and fourth regressions are less statistically significant, in each of the four regressions the coefficients on these variables are very close to zero and have no statistical significance. This is consistent with the notion that the "temperature" of the IPO market does not affect the longterm operating performance of these IPOs, as measured by the returns on assets or equity. These results are consistent with those of Buttimer, Hyland and Sanders (2005) for REIT IPOs' long-run, stock market performance, and they are a particularly useful confirmation, since the use of operating performance avoids much of the baggage associated with the use of stock returns and resulting implications about efficient markets.

\section{IPO Activity and Aggregate Real Estate Investment}

The results above are consistent with the hypothesis that REIT IPO cycles are driven by the demand for investment capital, rather than adverse selection. To corroborate these results, we conclude our analysis by examining whether or not there is a link between IPO volume and future investment levels. In an effort to show that REIT IPOs lead times of growth in the sector, we estimate two measures of supply and demand for real estate as functions of lagged REIT IPO proceeds. Our first measure deals with the growth in REIT assets. Specifically, for all seasoned REITs (defined as those that have been public at least six quarters), we calculate the aggregate quarterly change in their total assets in real terms. As a robustness check, we also use the percentage of capacity utilized in the economy as determined by the Federal Reserve Board. Higher capacity utilization should spur demand for physical 
assets in general, and, in particular, real estate. This variable is used in practice as an indicator of real estate investment needs, ${ }^{18}$ and it is related in an intuitive way to our measures of real asset market performance.

Table 7 aggregate real estate investment as a function of REIT IPO market.

\begin{tabular}{|c|c|c|}
\hline Dependent Variable & $\begin{array}{l}\text { Seasoned REITs' } \Delta \text { (Assets) }{ }_{t} \\
\text { (1) }\end{array}$ & $\begin{array}{l}\text { Capacity Utilization } t_{t} \\
\text { (2) }\end{array}$ \\
\hline REIT IPO Proceeds (Qtr $t-1)$ & $\begin{array}{r}2.055 \\
(1.11)\end{array}$ & $\begin{array}{l}0.0644^{*} \\
(1.86)\end{array}$ \\
\hline REIT IPO Proceeds (Qtr $t-2)$ & $\begin{array}{l}-0.249 \\
(-0.16)\end{array}$ & $\begin{array}{r}0.039 \\
(1.33)\end{array}$ \\
\hline REIT IPO Proceeds (Qtr $t-3)$ & $\begin{array}{l}-0.743 \\
(-0.41)\end{array}$ & $\begin{array}{l}-0.004 \\
(-0.12)\end{array}$ \\
\hline REIT IPO Proceeds (Qtr $t-4)$ & $\begin{array}{l}-1.403 \\
(-0.92)\end{array}$ & $\begin{array}{l}-0.005 \\
(-0.18)\end{array}$ \\
\hline REIT IPO Proceeds (Qtr t-5) & $\begin{array}{l}3.553^{* *} \\
(2.40)\end{array}$ & $\begin{array}{l}0.049^{* *} \\
(2.10)\end{array}$ \\
\hline REIT IPO Proceeds (Qtr $t-6)$ & $\begin{array}{r}1.332 \\
(0.90)\end{array}$ & $\begin{array}{l}0.059^{* *} \\
(2.19)\end{array}$ \\
\hline Constant & $\begin{array}{l}25.5^{* * *} \\
(2.73)\end{array}$ & $\begin{array}{l}80.143^{* * *} \\
(122.85)\end{array}$ \\
\hline $\begin{array}{l}\text { Number of observations } \\
\text { Adjusted } R \text {-squared }\end{array}$ & $\begin{array}{l}71 \\
0.086\end{array}$ & $\begin{array}{l}71 \\
0.065\end{array}$ \\
\hline \multicolumn{3}{|c|}{$\begin{array}{l}F \text { test ( } p \text { value) for hypothesis that sum of coefficients on REIT IPO proceeds } \\
(Q \operatorname{tr} t-n) \text { equals zero }\end{array}$} \\
\hline & $\begin{array}{l}4.03^{* *} \\
(0.05)\end{array}$ & $\begin{array}{l}13.91^{* * *} \\
(0.00)\end{array}$ \\
\hline
\end{tabular}

Notes: This table presents an ordinary least squares (OLS) regression of two proxies for aggregate U.S. real estate investment on previous periods' proceeds from REIT IPOs over the 1981 to 1998 period. The dependent variable in column one is the quarterly change in the total assets of seasoned REITs, in real dollars. Seasoned REITs are defined as all REITs on Compustat that have been public for more than six quarters. The dependent variable in column two is the capacity utilization rate: total industry (percent of capacity, seasonally adjusted), from the Federal Reserve Board. REIT IPO Proceeds $(Q \operatorname{tr} t)$ is defined as the (real) dollars raised by REIT IPOs in quarter $t$ (in millions of dollars). $t$ statistics for each coefficient are in parentheses and are based on Newey-West (1987) standard errors that are robust to autocorrelation and heteroskedasticity. ${ }^{*},{ }^{* *}$ and ${ }^{* *}$ denote significance at the $0.10,0.05$ and 0.01 levels, respectively. The table also presents the number of observations, the adjusted $R$-squared and an $F$ test for the hypothesis that the sum of the coefficients on the six lagged REIT IPO variables is zero. The $p$ value for this $F$ test is in parentheses.

Table 7 shows the results of this analysis. In both regressions, the independent variables are the aggregate dollar amount of REIT IPO proceeds over the prior six quarters, measured in real terms. The dependent variable in the first regression is the quarterly change in the total assets of seasoned REITs in real dollars. While this regression has just one significant coefficient (3.553 on IPO proceeds lagged five quarters, significant at the 0.05 level), ${ }^{19}$ an $F$ test for the hypothesis that the sum of the six coefficients is zero can be rejected at the $5 \%$ significance level. The dependent variable in the second regression is the

\footnotetext{
${ }^{18}$ Examples are Schiller and Buzard (2002) and Deloitte (2004).

${ }^{19}$ The $t$ statistics for each coefficient are based on Newey-West (1987) standard errors, which are robust to autocorrelation and heteroskedasticity.
} 
aggregate industry capacity utilization rate, which is a percentage of total capacity, seasonally adjusted. ${ }^{20}$ As in the initial regression, the coefficient of IPO volume lagged five quarters is positive and significant; in addition, the first and sixth lags are also positive and significant. The $F$ test for the hypothesis that the sum of the six coefficients is zero can now be rejected at the 0.01 level.

While no claims about causality can be made here, overall, Table 7 shows that lagged real REIT IPO proceeds are associated with greater real growth in seasoned REITs and higher economy-wide capacity utilization. Thus, REITs appear to raise money in advance of growth in the real estate sector. This is consistent with the idea that supply and demand for real estate at least partially determine IPO waves.

\section{Conclusion}

IPOs have presented many puzzling empirical regularities, including underpricing, poor longterm performance, and the presence of cycles or waves. The last of these-the existence of hot and cold markets-has been explained by competing theories, primarily based on asymmetric information or time-varying supply and demand for firms' underlying assets. We examine and test these explanations using REIT IPOs over the 1980 to 1998 period. REITs provide an interesting experiment because of the reduced asymmetry between managers and the market (compared to regular corporations) and because of the relative ease with which one can observe the conditions of the market for their underlying assets.

We find that the heat of the IPO market as measured both by IPO volume (hot supply) and initial-day return (hot demand) is related to the state of the underlying real markets and relative REIT prices. We also find that while the performance of the real market is significant in explaining the supplyside definition of hot markets, dividend yield is both statistically and economically more significant and is also the only variable significantly related to the demand-side definition of hot markets.

While these tests are consistent with demand for underlying assets driving IPO cycles, they do not provide direct evidence of whether the quality of firms going public varies across the IPO cycle (e.g., if low-quality firms use a hot market as a time to go public). To test this more directly, we test for differences in post-IPO abnormal operating performance between firms that go public in hot markets versus in cold markets. Using two measures of abnormal operating performance and our two characterizations of hot and cold markets, we find no evidence of a difference in post-IPO operating performance over the cycles. As a final test, we show that lagged real REIT IPO proceeds are associated

\footnotetext{
${ }^{20}$ This time series is from the Federal Reserve and is available through WRDS.
} 
with greater real growth in seasoned REITs and higher economy-wide capacity utilization. This is further support for the notion that, rather than low-quality firms taking advantage of opportunistic pricing, variation in the supply and demand for real estate drives IPO cycles.

\section{References}

Allen, F. and G.R. Faulhaber. 1989. Signaling by Underpricing in the IPO Market. Journal of Financial Economics 23: 302-323.

Baker, M. and J. Wurgler. 2000. The Equity Share in New Issues and Aggregate Stock Returns. Journal of Finance 55: 2219-2257.

Barkham, R. and D. Geltner. 1995. Price Discovery in American and British Property Markets. Real Estate Economics 23: 21-44.

Bradley, D. and B. Jordan. 2002. Partial Adjustment to Public Information and IPO Underpricing. Journal of Financial and Quantitative Analysis 37: 595-616.

Brav, A. and P. Gompers. 1997. Myth or Reality? The Long-Run Underperformance of Initial Public Offerings: Evidence from Venture and Nonventure Capital-Backed Companies. Journal of Finance 52: 1791-1821.

Buttimer, R.J., D.C. Hyland and A.B. Sanders. 2005. REITs, IPOWaves, and Long-Run Performance. Real Estate Economics 33: 51-87.

Chemmanur, T.J. and P. Fulghieri. 1999. A Theory of the Going-Public Decision. Review of Financial Studies 12: 249-279.

Choe, H., R. Masulis and V. Nanda. 1993. Common Stock Offerings Across the Business Cycle. Journal of Empirical Finance 1: 3-31.

Deloitte. 2004. Real Estate Capital Markets Industry Outlook-Mid- 2004 \& Beyond. Available at http://www.deloitte.com/dtt/cda/doc/content/ CapMarkets Top Ten 2004(1).pdf.

Fisher, J., D. Geltner and J.R. Webb. 1994. Value Indices of Commercial Real Estate: A Comparison of Index Construction Methods. Journal of Real Estate Finance and Economics 9: 137-164.

Friday, H.S., S. Howton and S. Howton. 2000. Anomalous Evidence on Operating Performance Following Seasoned Equity Offerings: The Case of REITs. Financial Management 30: 76-87.

Gallagher, M. and A. Wood. 1999. Fear of Overbuilding in the Office Sector: How Real Is the Risk and Can We Predict It? Journal of Real Estate Research 17: 3- 32. 
Geltner, D. and W. Goetzmann. 2000. Two Decades of Commercial Property Returns: A RepeatedMeasures Regression-Based Version of the NCREIF Index. Journal of Real Estate Finance and Economics 21: 5-21.

Ghosh, C., R. Nag and C.F. Sirmans. 1998. Are REIT Seasoned Equity Offerings Underpriced? Real Estate Finance 27: 19-23.

Ghosh, C., C.F. Sirmans and R. Nag. 1999. An Analysis of SEOs by Equity REITs, 1991 to 1995. Journal of Real Estate Finance and Economics 19: 175-192.

Gompers, P. and J. Lerner. 2003. The Really Long-Run Performance of Initial Public Offerings: The PreNasdaq Evidence. Journal of Finance 58: 1355-1392.

Gyourko, J. and D.B. Keim. 1993. Risks and Returns of Investing in Real Estate: Evidence from a Real Estate Stock Index. Financial Analysts Journal 49: 39-46.

Hartzell, J.C., J.G. Kallberg, C.H. Liu and A. Mainemer. 2003. REIT IPOs and the Real Asset Market. Working paper. The University of Texas at Austin and New York University.

Helwege, J. and N. Liang. 2004. Initial Public Offerings in Hot and Cold Markets. Journal of Financial and Quantitative Analysis 39: 541-569.

Ibbotson, R. and J. Jaffe. 1975. Hot Issue Markets. Journal of Finance 30: 1027-1042.

Ibbotson, R. and J.R. Ritter. 1995. Initial Public Offerings. R. Jarrow, V. Maksimovic and W.T. Ziemba, editors. Handbooks in Operations Research and Management Science, Vol. 9. Elsevier, Amsterdam. pp. 993-1016.

Ibbotson, R., J. Sindelar and J.R. Ritter. 1994. The Markets' Problem with the Pricing of IPOs. Journal of Applied Corporate Finance 6: 66-74.

Jovanovic, B. and P. Rousseau. 2003. The Q-Theory of IPOs. Working paper. New York University.

Kallberg, J.G., C.H. Liu and A. Srinivasan. 2003. Dividend Pricing Models and REITs. Real Estate Economics 31: $435-450$.

Ling, D.C. and M. Ryngaert. 1997. Valuation Uncertainty, Institutional Involvement, and the Underpricing of IPOs: The Case of REITs. Journal of Financial Economics 43: 433-456.

Liu, C.H. and J. Mei. 1992. The Predictability of Returns on Equity REITs and Their Co-Movement with Other Assets. Journal of Real Estate Finance and Economics 5: 401-418.

Ljungqvist, A., V.K. Nanda and R. Singh. 2003. Hot Markets, Investor Sentiment, and IPO Pricing. Working paper. The Center for Economic Policy Research Discussion Papers.

Ljungqvist, A. and W. Wilhelm. 2003. IPO Pricing in the Dot.com Bubble. Journal of Finance 58: 723-752. 
Logue, D. 1973. On the Pricing of Unseasoned Equity Issues: 1965-1969. Journal of Financial and Quantitative Analysis 8: 91-103.

Loughran, T. and J.R. Ritter. 1995. The New Issues Puzzle. Journal of Finance 50: 23-51.

Loughran, T., J.R. Ritter and K. Rydqvist. 1994. Initial Public Offerings: International Insights. Pacific Basin Finance Journal 2: 165-199.

Lowry, M. and G.W. Schwert. 2002. IPO Market Cycles: Bubbles or Sequential Learning? Journal of Finance 57: 1171-1200.

Lucas, D.J. and R. McDonald. 1990. Equity Issues and Stock Price Dynamics. Journal of Finance 45: 10191043.

Miles, M. 1997.AFoundation for the Strategic Real Estate Allocation: The Space Market Index. Real Estate Finance 13: 23-30.

Miles, M. and D. Guilkey. 1998. A Tactical Look at the Space Market Index. Real Estate Finance 14: 3945.

Newey, W. and K. West. 1987. A Simple, Positive, Semi-Definite, Heteroskedasticity and Autocorrelation Consistent Covariance Matrix. Econometrica 55: 703-708.

Niehaus, G. and G. Roth. 1999. Insider Trading, Equity Issuance and CEO Turnover in Firms Subject to Securities Class Actions. Financial Management 28: 52-72.

Ritter, J.R. 1991. The Long-Run Performance of Initial Public Offerings. Journal of Finance 46: 3-28.

Rock, K. 1986. Why New Issues Are Underpriced. Journal of Financial Economics 15: 187-212.

Schiller, T. and K. Buzard. 2002. Regional Highlights, Fourth Quarter 2002. Federal Reserve Bank of Philadelphia. Available at http://www.phil.frb.org/files/reghigh/ rh0402.pdf. Schultz, P. 2003. Pseudo Market Timing and the Long-Run Underperformance of IPOs. Journal of Finance 58: 483-517.

Sherman, A.E. 1999. Underwriter Cost and the Effects of Shelf Registration on Due Diligence. Financial Management 28: 5-19.

Spiess, K. and J. Affleck-Graves. 1995. Long-Run Performance Following Seasoned Equity Offerings. Journal of Financial Economics 24: 243-267.

Stoughton, N.M., K. Wong and J. Zechner. 2001. IPOs and Product Quality. Journal of Business 74: 375408.

Wang, K., S.H. Chan and G. Gau. 1992. Initial Public Offerings of Equity Securities: Anomalous Evidence Using REITs. Journal of Financial Economics 31: 381-410. 
Welch, I. 1989. Seasoned Offerings, Imitation Costs, and the Underpricing of Initial Public Offerings. Journal of Finance 44: 421-449.

Welch, I. 1992. Sequential Sales, Learning, and Cascades. Journal of Finance 48: 695- 728. 